\title{
Between exclusion and political engagement: Conceptualizing young people's everyday politics in the post-war setting of Sri Lanka
}

\author{
Fazeeha Azmi, Cathrine Brun and Ragnhild Lund
}

(Equal Authorship)

\section{Final version before proofs, reference for published work:}

Azmi, F., C. Brun, R. Lund (2015) Between exclusion and political engagement: Conceptualizing young people's everyday politics in the post-war setting of Sri Lanka. In Geographies of Children and Young People. Politics, Citizenship and Rights, edited by T. Skelton, K.P. Kallio and S. Mills. Pp. 345 - 362. Springer.

\begin{abstract}
Drawing on findings from research on youths in post-war eastern Sri Lanka, the aim of this chapter is twofold: first, to develop a framework for understanding young people's everyday engagements with politics in the context of the transitions that a post-war setting involves, and second to develop an understanding of young people's political everyday engagement in a context where the state has clearly and quickly moved from a post-war stage to a development stage. The authors find that the different experiences of the violent past and a politicized post-war setting continue to play a role in young people's lives and form a constrained context in which their political engagement is shaped. Unemployment and lack of involvement in on-going development initiatives by the state exclude Tamil and Muslim youths from political spaces and from having a political voice at the national level. Instead they are enmeshed in societal and spatial power relations in a political environment that impacts negatively on their identity construction and subjectivities.
\end{abstract}

Key words: Youth, everyday politics, post-war transition, exclusion, Sri Lanka 


\section{Introduction}

Conflicts do not disappear easily and become replaced by a peaceful state of existence (Moore, 2000). Moving from war to post-war has been a profound transition in young people's lives in Sri Lanka. The official government story of transition towards peace in the country and the experience of that story by young people in war-affected areas are entirely different. Young people's political engagement in the post-war setting of Sri Lanka explains a particular generation's experience of the transitions taking place from war to post-war and further towards an unknown future.

This chapter analyzes the ways in which Tamil and Muslim young people become political through particular experiences of exclusion in the official discourses on post-conflict issues as well as in their access to employment and welfare, participation, and development. The political is conceptualized as the relationship between electoral politics, state policies, and the ways in which people may struggle to find their place and fight for inclusion and emancipation from what they see as marginal places (Azmi et al., 2013). The aim is to unravel the spaces of everyday life, and hence explore how young people's political engagement is developed. Achieving this aim, will contribute to understand how differences and positionalities are negotiated through access to particular social spaces through which influence may be gained (for example Bartos, 2015). Thus, reference is made to recent geographical work on youths that has contributed to an understanding of how young people make, politicize, and challenge space (Jeffrey, 2008; Wood, 2012).

After a discussion of the context and methodology, the chapter provides a discussion of the transformation that takes place from war to a stage of post-war and young people's experience of such a transformation in a war-affected area of eastern Sri Lanka in relation to the official discourse of transformation created by the state, which mainly concerns the physical infrastructural development and reconciliation (Schubert, 2013; Uyangoda, 2011; 2012). The purpose of the discussion is to develop an understanding of young people's political everyday engagement in a context in which the state has clearly and quickly moved from a post-war stage to a development stage, but the different experiences of the violent past and a politicized post-war setting continue to play a role in young people's lives and form an important context in which their political engagement is shaped. The following section introduces the Sri Lankan context and methodology, and is followed by a 
presentation of the analytical framework used in the study. Thereafter, young people's experiences of exclusion from the official discourse on Sri Lanka after the war are discussed, and some of the spaces of political engagement identified by the young people are analyzed. Based on data collected during the period 2009-2014, the final analytical section explores the changing conditions for political engagements among young people. The chapter concludes with reflections on the spatial and temporal dimensions of the relationship between social exclusion and political engagement among young Tamils and Muslims in eastern Sri Lanka since the war ended in 2009.

\section{Context and methodology}

Youths' involvement in politics in Sri Lanka dates backs to the pre-independence period, but it was not until independence was gained in 1948 that the country saw the development of youth uprisings by rural youths, unemployed educated young people, and nationalist groups mobilizing around ethnicity. While political issues in Sri Lanka before the 1960s were centred on socio-economic stratification and ethnic identities, repeated violent political actions in the late 1960s affected a whole generation of youths (Amarasuriya, 2009; Fernando, 2002; Hettige, 2008). Discrimination was based on class, caste, ethnicity, religion, ideology, place of origin, education, and employment, resulting in youth uprisings against the socio-economic and political exclusions that continued during the 1970s and 1980s and took the form of paramilitary political action. The civil war was fought between the Liberation Tigers of Tamil Eelam (LTTE) and the Sinhalese-dominated Sri Lankan government forces from 1983 to 2009. It was not just a bipartisan conflict, but spread beyond the ethnic boundary between the majority Sinhalese and the minority Tamils, to include also the minority group of Muslims (recognized as an ethnic group in Sri Lanka). As a result of this history of youth uprisings and conflict, youth politics in the country have been understood as violent and troublesome. During three decades of war, the entire nation suffered in various ways. People in general lived in fear and mistrust, and youths were vulnerable in multiple ways: they either served as combatants or hid themselves from public spaces in fear of forceful recruitment and to avoid surveillance by the government security forces. 
In eastern Sri Lanka, Tamils and Muslims were both profoundly affected by displacement, loss of family members, lack of education and livelihoods opportunities, and restrictions to their mobility. In terms of political participation, while Muslim youths' political participation continued through their affiliation with mainstream political parties and through the Sri Lanka Muslim Congress, Tamil youths lacked access to exercise their political rights through political parties; their only avenue for political participation was through militarism. Since the defeat of the LTTE in the east in 2007 (and in the north in May 2009), the government of Sri Lanka has initiated large-scale development and infrastructure projects in the eastern part of the country. However, the recovery process has been fraught due to differing access to resources and unequal progress in recovery (Brun and Lund, 2009; Hyndman, 2007; International Crisis Group 2009; Ruwanpura, 2009).For young people living in northern and eastern Sri Lanka, the period immediately after the war was characterized by a continuation of militarized social life. During the time of research, the official political discourse has been dominated by the strong leadership of President Mahinda Rajapaksa's Sri Lanka Freedom Party and has rhetorically moved from militarism to development and recovery. In this context, many people are fearful of speaking out or being politically active. Instead, they try to mobilize and express their opinions in less obvious ways by not articulating their opinions openly or by having a discrete presence and engaging politically from safe places. As youth politics have traditionally been considered problematic in Sri Lanka, there is a need to investigate how 'normal youths' (i.e. young people outside the political parties) engage in politics today in eastern Sri Lanka.

Despite the end of war in 2009, the areas in which fieldwork was undertaken were still militarized and people there continued to fear for their safety. In such circumstances, the ethical considerations required for understanding researchers' responsibilities become crucial in order not to cause any harm. The measures taken during fieldwork to maintain the safety of the research participants and researchers alike have been described extensively elsewhere (Azmi et al., 2013; Brun, 2013 Lund, 2012), but in short safe spaces were enabled by encouraging the young people to help in determining where interviews could be held and what could be talked about. To maintain anonymity, the locations where the fieldwork took place were not disclosed, but the areas under study represented 
both urban and rural areas, areas formerly controlled by the LTTE, areas affected by war and the presence of LTTE, and areas with little LTTE influence but that were nevertheless affected by war.

The fieldwork and follow-up interviews were conducted in three stages in between 2009 and 2011, and 2014. In the first stage of the study, in 2009, key informants were interviewed, including government officers in charge of youth projects, persons representing civil society, and other resource persons. In addition, youth organizations and other places where young people (Tamils and Muslims) are present were visited, including playgrounds, universities, sports arena, and NGOs. The second stage was developed between 2009 and 2011. Group discussions were held with university student groups, sports groups, internally displaced young people, groups of young people living in a tsunami resettlement village, and women activists and NGO workers. In order to obtain updated information, youths we interviewed between 2009 and 2011 were approached by phone in February and March 2014. Seven former interviewees were reached through helpful parents and friends, and were willing to share the latest news in their lives and in their villages.

\section{Political engagement and social inclusion and exclusion - a youth-centred perspective}

Literature on young people and politics emphasizes the intersections between micro- and macro politics and Politics (with a capital 'P') (Häkli and Kallio, 2013; O’Toole, 2003; Skelton, 2010) and the accompanying coming together of different political practices (also see Mills and Duckett, 2015). There are particular connections between politics and youths in Sri Lanka that need to be understood in order for young people's politics to be understood. As mentioned above, youths' participation in politics in Sri Lanka has been perceived as inherently violent. Youth protests erupted initially in the 1960s and continued to unsettle the politics of the country until it cumulated in war in 1983. While much has changed in Sri Lankan society since the war started in the early 1980s, experiences of social exclusion have persisted among Tamil and Muslim youths currently living in the eastern part of the country, as shown in this chapter.

Sen's (2000) research on social exclusion has focused on relational features with deprivation of capability among poor people. Recently, such research has been directed towards understanding 
structural as well as social processes that lead to individuals and groups living on the margins of society (Gingrich, 2008; Vandeyar, 2013). Understanding political engagement based on social exclusion focuses primarily on relational issues and social ties, such as family, friends, local communities, state services and institutions, and more generally the societies to which individuals belong (Bhalla and Lapeyre, 1997). Such a multi-dimensional approach to understanding social exclusion includes the closely interrelated dimensions of economic, social, and political processes. The political dimension of social exclusion refers to citizenship rights namely civil, political, and socio-economic rights (Staeheli, Attoh, \& Mitchell, 2013) and consequently a range of formal and informal processes that determine people's inclusion in and exclusion from a variety of symbolic and material spaces and resources (Brun, 2003).

An important connection between social exclusion/inclusion and political engagements is formed by the social spaces in which young people engage in politics. For example, the more safe and included people feel, the more involved and vocal they can be. In the research context presented in this chapter, such spaces are limited to the family or the university. However, when young people feel excluded they also feel voiceless. In the case study in question, this happens when access to education and work is controlled by others or when participation in development activities is denied to them. The emotions triggered by the experience of social exclusion gave rise to political reflexivity among the young people interviewed (Lund, 2012).

Kallio and Häkli (2011) distinguish between political presence and political involvement in order to understand how aware young people are of the political aspects of their actions when engaging politically. Their distinction is useful for understanding the emotional and reflective process towards being and acting political among young people in eastern Sri Lanka. Those young people's political engagements in various social spaces and how they make safe spaces for political participation have been analyzed in an earlier article (Azmi et al., 2013). The discussion is continued here, by analyzing the particular ways in which young people relate to, identify with, and dissociate themselves from the state, and by particularly considering the official discourses of the state and the president after the war, and how the young people associate with those discourses. To facilitate the analysis, this chapter also examines the axis between voiceless and vocal politics (also derived from 
Kallio and Häkli, 2011), which concerns how much voice young people have in politics. In this regard, the aim to make more explicit the spatialities of the youth-centered perspectives on the political and politics, as much of the literature on social exclusion ignores its spatial aspects (Cass, Shove, \& Urry, 2005). In the studied context, young people manoeuvre spaces of restricted freedom of speech and high security risks, and make safe spaces for political engagement. Their claims of lack of access and socio-spatial exclusion unravel both earlier and contemporary exclusions.

\section{Sri Lanka's official discourse of post-war development and the young people in eastern part of the country}

This section examines the extent to which young people feel included in the reality portrayed by the state/government and President Mahinda Rajapakse (MR), and how their political presence and involvement are reflected in processes of inclusion and exclusion.

Throughout Sri Lanka the president's and the official government's discourse is prominent in the state-controlled media. In the programs broadcast on the TV channels accessible to most people in the eastern part of the country, MR the president is portrayed as a hero who downplays minority status and ethnic differences. Almost daily on the news programs, the president is shown taking part in the opening ceremonies for roads, bridges, and schools, or ceremonies in which letters are handed over containing the promise of new development projects in the future. Although the ceremonies are not necessarily located in the eastern part of the country, they give an impression of a president who takes development seriously while talking about the government's achievements in eradicating terrorism and creating a peaceful life for its citizens. When the ceremonies include Tamils, MR speaks in Tamil. The printed Tamil-speaking media (Nawamani Veerakesari, Vidivelli, Sudar Oli, and Muslim Murasu) are critical of the government in general, but are still subject to governmental control and censorship. Young people are highly aware of this bias, and therefore relating to the official discourse is an essential way of understanding how people experience social exclusion, as shown in this section.

\section{One nation/one community: there are no minorities anymore}


Understanding ethnicity in the Sri Lankan context is closely connected to the notion of 'minority'. The terms 'minority' and 'majority' are not only about shares and numbers in the Sri Lankan context, but also about the political and 'ethical', whereby the minority must be subservient to the majority (Ismail, 2001). While Muslims have been termed a 'good' minority because they have accepted their status as a minority in politics, Tamils have been considered a problem because they have refused to accept the status of minority and have fought for a separate state. Hence, there are good reasons to find out how the prominent discourse of no minorities and the irrelevance of ethnicity resonate with the young people.

In his speech at the ceremonial opening of Parliament on 19 May 2009, MR said:

We removed the word minorities from our vocabulary three years ago. No longer are there Tamils, Muslims, Burghers, Malays and any other minorities. There are only two peoples in this country. One is the people that love this country. The other comprises the small groups that have no love for the land of their birth. Those who do not love their country are now a lesser group. (Rajapaksa, 2009)

MR was implying that for 30 years there was a terrorist problem in Sri Lanka, not an ethnic conflict, but the root causes of the conflict have not had any recognition in this official discourse. MR attempts to recast the paradigms of ethnicity that have divided the country and continue to downplay ethnic identities (Schubert, 2013). Schubert shows how MR, through national plans such as Mahinda Chinathanaya, the development plan for the eastern regions, has formulated a very clear victim-victor discourse, which portrays all Sri Lankans as victims against the LTTE:

a community united by the shared experience of the LTTE's 'murderous terrorism' ... the President builds on the idea of this multi-ethnic body, to point out that the collective identity of this multi-ethnic body (or nation) was forged because of the common/shared experiences of victimisation at the hands of the LTTE. (Schubert, 2013, pp. 11-12) 
Although the sentimental 'one nation' rhetoric received wide attention in the media (especially appealing to the majority), people from minority groups felt it hard to accept a 'false one nation identity', due to the longstanding tension between majority and minorities and the differing consequences of the war on them. The current situation raises questions regarding the 'one nation' when it comes to the identity of minorities, as the increasingly ethnicized everyday life of Sri Lankans shows that the post-war years have not helped to remove the term 'minority' from the vocabulary; rather, the term 'minority' is acquiring a thick negative meaning. In contrast to the official discourse, Tamil young people are still left with the experience of losing the war and an intense feeling of continuing to be a minority, and they feel humiliated. Similarly, Muslim young people in the eastern part of Sri Lanka feel that their identity is being threatened, and the expansion of Sinhalese settlements in particular towards Muslim inhabited areas is perceived as a threat that continues to make ethnicity a prominent aspect of their daily lives. (For a detailed study on youth identity and geopolitical contestation in in Herzegovina see Laketa, 2015).

During the interviews, ethnicity often emerged as a theme around which young people became political. The interrelated identities of ethnicity and minority continue to influence their political awareness and agency. In 2009, 2010, and in the follow-up interviews held in 2014, all young Tamils and Muslims interviewed in eastern Sri Lanka saw their position in society as marginal and emphasized that the major cause was ethnicity. Today, youths emphasize the ethnic boundaries in terms of eastern origin, language, and religion. Both Muslims and Tamils feel that they are largely excluded from public places elsewhere (i.e. other than their local areas) and are reluctant to go to the capital, Colombo, because they do not speak Sinhalese and feel that people look down upon them with suspicion due to their attire, which reveal cultural/ethnic/religious identities. In 2014, young people reported the following restrictions and disillusionments:

Ethnicity is not a problem as long as we stay in the east. LTTE is also defeated. (Young Muslim man, telephone interview March 2014) 
We went on a family trip to Colombo. It looks like a different country if we compare [it] with our village. We are also people born here in Sri Lanka ... but born in a wrong place. (Young Tamil woman, telephone interview March 2014)

Clearly, the young people felt excluded from MR's one-nation discourse, and they have no reason to feel unity with the Sinhalese majority. They reflected the experience of being distanced from the rest of the country in many ways - that their world was limited to the eastern part of Sri Lanka. In their understanding, they continued to be a marginalized minority and their ethnic identities continued to play a major role in their exclusion when they related to the national context in terms of employment and education opportunities. Feelings of being neglected and rejected on ethno-religious grounds caused deep frustrations. Consequently, the President's attempt to define a common identity will constitute a challenge and perhaps an unrealistic aim, as Sri Lankans continue to be divided economically, politically, religiously, and ethnically.

\section{Economic development and democracy}

A key feature of post-war Sri Lanka and its official discourse is how the 'post-war' discourse has been made irrelevant and replaced with a discourse on development, largely as economic and infrastructural development. In terms of infrastructure development in the eastern part of the country, a large-scale infrastructure development program titled Negenahira Navodaya (Eastern Revival) was implemented when the government fully eradicated the LTTE from the east and established its military power in the Eastern Province in 2007.

The solution to the conflict and what has been described as a terrorist problem is disarmament, democracy, and development:

Economic and infrastructure development seem to constitute the mainstay of the Rajapaksa government's approach to managing potential ethnic tensions in the post-civil war phase. The approach 
is based on the notion that the political and economic reintegration of the Tamil minority into the Sri Lankan state will be easier when the benefits of rapid economic and infrastructure development are felt. (Uyangoda, 2011, p. 135)

In this sense, economic development has been considered the main strategy for addressing and resolving minority grievances. Uyangoda (2012) explores possibilities for reconciliation after the war. He questions the ability of Sihnalese political leadership to understand and respond to the worries of the war-affected people, and describes how the future in the post-war situation is differently perceived among Sinhalese and Tamils.

According to Schubert (2013), MR has made it clear that future developments in the north and east of the country will be heavily militarized. After the end of the war, military personnel were employed in the construction, service, and agricultural sectors in other parts of the country. In the eastern part of the country, involvement in similar activities was not viewed positively by youths interviewed even though the military did not exert force to the same extent as earlier, and which was once part of everyday life. As Goodhand (2012, p. 133) says: 'Those living in the north and east have limited political voice or recourse to justice, and therefore lack the power to influence or shape development processes that are rapidly transforming the Tamil-majority region.'

During the interviews, the young people recognized that the improvements in infrastructure and development have made life easier: roads and bridges in particular have reduced travelling times, and there is improved access to formal education, including classes in English language, tailoring, and computing. There is considerable NGO involvement in the development of youths' skills. However, the different types of training and skills-development programs targeted at youths have not led to them securing their anticipated jobs. For example, when they do not have customers to make clothes for in their villages, due to the villagers being too poor to buy the clothes, the training in tailoring has little value. Whether organized by the government or NGOs, it is important that skills training is related to existing demands in villages or at least to demands in the wider region. The interviewed youths also felt that such developments are comparatively poor and low in quality compared to developments of other areas of the country, especially in Colombo. In addition, they highlighted that although they 
needed such developments, they also had other priorities such as access to the labor market and the same services as found elsewhere in the country:

Although education is much better ... employment is so limited and [the] government's role in employment is something related to politics. (Young Muslim man, telephone interview February 2014)

The majority of the interviewed youths expressed continued frustrations about the exclusion of Tamilspeaking youths from employment in higher decision-making positions at the national level. Even the government of Sri Lanka's youth policy acknowledges the exclusion of youths from minority ethnic and religious groups (Ministry of Youth Affairs and Skills Development, 2014), p. 16). Discriminated and exploited youth groups are treated as priority target groups that deserve special attention. In February 2014, when some of the young people interviewed in 2009 and 2010 were interviewed again, many lamented the lack of relevant development initiatives undertaken by the state. Jobs in the public sector are scarce, people from outside take up the available jobs, and young people are forced to move long distances or travel abroad to secure a better future. For youths who grew up with war and who do not have much exposure to outside world, confronting unfamiliar spaces locally and globally is both a threat and a challenge:

Opportunities for employment are a big problem ... especially for youths. (Young Tamil man, telephone interview March 2014)

Although youth unemployment continues to remain a critical problem throughout Sri Lanka (Ministry of Youth Affairs and Skills Development, 2014), youths from the eastern part are marginalized in the employment market and also face underemployment. The war has changed the economic base of the villages and households, making them more vulnerable to poverty. In the absence of an attractive private sector, youths from eastern Sri Lanka have to depend on public sector employment. Although post-war development paved the way for vast infrastructural programs directly handled by the 
presidential task force under Basil Rajapaksa (Cabinet Minister of Economic Development, and MR's brother), such developments fail to meet the real needs of the war-affected people. This trend has been highlighted and criticized repeatedly by Tamil politicians, academics, and researchers. Post-war development programs and projects should be planned in a way that recognizes the victims. The state should not undermine the fact that it was poor youths from deprived and marginalized communities who resorted to political violence against the state in the first place.

With regard to democracy, reconciliation, and politics, young people are generally highly disillusioned and feel excluded from official discourses:

What we hear about reconciliation has become a joke. Reconciliation is not only about arranging meetings/workshops/sports meets friendly visits for youths from all communities ... they are just shows only ... real understanding should be cultivated in the minds of people. (Young Muslim man, telephone interview February 2014)

In the media, 'reconciliation' has been a popular word in the context of post-war Sri Lanka, although the meaning of the word is not well known among the people we interviewed. Uyangoda (2012) highlights the difference between the Western notion of reconciliation and the Sri Lankan government's conceptualization. While the former has liberal and Christian and Humanistic moral roots, highlighting peace and a situation of no victors and no losers, the latter's notion of reconciliation is one of 'forget the past and move forward'. In this regard, it is important that 'reconciliation' cannot be instilled in people from the top through meetings, workshops, and sports meetings arranged by the state to demonstrate the participation of all ethnicities. Such events take place in all of the war-affected areas, including those in the east. However, the real output of such programs may be questioned.

\section{Creating spaces of political engagement}

Experiences of exclusion are expressed as anger, resignation, fear, and frustration. This section unravels how young people in the eastern part of the country engage in politics following their 
experience of exclusion, the extent to which they associate with and pursue a political voice, and the ways in which they are excluded/silenced or enabled to create safe spaces for inclusion.

\section{Formal/informal politics}

Young people relate to politics in different ways. From the interviews held in 2009 and 2010 until the follow-up interviews in 2014, an increasing critique of formal politics and decreasing faith in politicians was observed. The young people said that formal politics had become a farce and more open to direct criticism. Still, youths do not want to object openly to what politicians are doing, despite complaining about it in private:

Politics is openly criticized ... people are fed up as no politician come to our village. They visit only during the election ... I want to tell you more ... but [I am] scared to tell you over the phone. I am always skeptical. (Tamil young woman, telephone interview March 2014)

[The] President is making an effort to show the world that we are fine ... But we are not ... because we are forced to be silenced ... youths like us do not want any further problems in the country ... we have to tolerate the situation (Young Tamil man, who was president of a youth club, telephone interview March 2014)

Muslim and Tamil young people alike feel politically marginalized. They are aware that the 'correct' political connection is important in order to secure a job in the public sector. Considering their low level of trust in politicians and political parties, youths do not consider political parties the best avenue for participation and exerting influence on issues concerning them. Instead, many youths have turned to what they term 'informal politics' by which is meant when you involve with politics for your own interests and is often accompanied by corruption. Part of the explanation for this shift may be found in the employment situation in the eastern part of the country, which has created increasing competitiveness and vulnerability in the new society: 
I must tell you [that] people are more concerned about politics these days. They are more particular about selecting whom they want to send to Parliament or local government institutions. They are interested in national-level politics also ... but it is so sad to note that young people's involvement in politics targets only personal benefits ... they don't have a political vision ... if they believe the politician whom they support can give them a job or a promotion or get their transfers (government servants) done, then they vote for him. When they were in the university, they were making propagandas for a radical social change ... everything becomes 'zero' when they are coming out from the university. (Young Muslim woman, telephone interview March 2014)

\section{Exclusions: silencing}

In many cases, young people adopt silence as a political strategy. Silence may be used in the sense of political presence and political involvement. Voiceless political presence cannot simply be equated with nonparticipation. Youths' presence varies according to the social space in question. Tamils and Muslims use silence as a way to stay safe in unsafe spaces, but as shown below, silence may also be a strategy to challenge the status quo. Many young Tamils said they still felt that they were considered terrorists when encountering either the military in their own area or the majority Sinhalese outside their area. Raising one's voice in public may run the risk of harassment and abduction.

In 2009, young women pointed out that they were fearful and kept silent in order to keep a low profile when they had to pass unsafe places such as checkpoints, but they also kept silent because they did not want to be associated with the military or police. Their political strategies were thus founded in silence and non-performativity (Kallio and Häkli, 2011; Scott, 1985; Thrift, 2004):

It is in the private spaces, such as our homes, that we can dance, sing, and do many other things that we can't do in public spaces. There will be restrictions and we have to think about the society too. (Young Tamil woman, interview March 2010)

Since then, the military presence has become less visible, but the 'normalization' mentioned by Goodhand (2012, p. 133) still does not exist, and thus people are still cautious and even scared to talk 
about politically controversial topics. During the phone interviews in 2014, interviewees would often say things like 'I can't tell you over the phone' indicating fear in talking freely as there were suspicions that telephone lines were monitored.

Political engagement is thus closely related to the feeling of social inclusion and exclusion, as well as to what extent people feel safe and recognized as full members of the spaces in which they participate:

We do not talk politics or terrorism in public spaces. It will create unnecessary problems for us. (Tamil and Muslim women, group interview February 2009)

\section{Safe spaces for political engagements}

Most young people in eastern Sri Lanka position themselves outside politics by defining their participation in society outside party politics.

The young people interviewed identified the home - a private space - as the safest arena in which they could discuss politics. In this regard, they were particularly concerned about how the recovery projects in their areas were run by the government recruiting people from outside to work on the projects, thus contributing to the youths' feelings of exclusion from national politics. They mentioned that they would discuss the political system and how the political system should change to benefit the minorities in northern and eastern Sri Lanka, such as by introducing federalism. In private, they readily admitted that there is no place for the rights of minorities in the current system and they would come up with explicit political solutions. Given the history of war and militarism of the area, parents also continued to be unhappy about their children's involvement in politics because of the association between youths, politics, and violence. Thus, there is a dual exclusion, based on both ethnicity and generation, that enables young people to be politically vocal in controlled, generally private spaces, but with limited opportunities to transgress those spaces.

During fieldwork, it was found that when youths talked about their political interests and affiliation they were only comfortable about openly expressing their views to a person from their own 
ethnicity or to foreign researchers. This made the researchers (i.e. the authors of this chapter) attentive to the fact that when the youths considered it was 'safe' to be with them, they became vocal. These constructions of safe spaces during fieldwork contributed to understandings of how young people's political engagements unfold (overtly or covertly) in everyday life. Similarly, the experience made the researchers attentive to the youths' ability to negotiate spaces and be flexible in their engagements outside the private spaces that they considered safe.

Still, young people conform by participating in activities that are accepted as involving the participation of good citizens. The interviewed youths participated in youth groups, helped with arranging funerals, participated in anti-alcohol campaigns, and organized sports meetings and other communal activities. They saw their engagement as a productive way of contributing to society but also as a way to gain status in society; they were building safe spaces for participation that might also provide access to political engagement. The youth clubs (which are organized by the government) were particularly seen as an opportunity to gain access to politics and politicians, who are often involved in club activities. Such spaces of political engagement represent a way for youths to engage with the political, but do not open up possibilities to challenge the existing system and mainstream politics and hence are a form of voicelessness. Nevertheless, youth clubs represent an alternative space that may help young people to gain status in their community. Even if youths cannot make the clubs safe places for vocal political involvement, they can influence the spaces and develop their own political involvement.

\section{Changing conditions for relating to the political}

The extent to which the historical changes in Sri Lanka since the end of the war have affected young people's political engagement; a democratic political space for youths lies in the acceptance of youths and their past. Formal political structures should be constructed to allow the voices of the youths to be heard. Are there more possibilities for political participation today, and have the contexts of enabling or constraining political participation changed? Following a group of young people over a time period of five years has indicated that a number of changes have occurred in their lives as they have moved 
towards adulthood. The coming together of different time scales - the history of transformation from war to post-war and the young people's individual histories from young to adulthood - can be understood by looking at the changes in the lives of university students.

It is possible to identify cautious optimism with regard to what politics can achieve, as two of the research participants pointed out:

Once people were afraid of being young in the east, but now the situation has improved. We feel a little bit fearless and we want this situation in the future too. (Muslim female student, interview March 2010)

I think young people are important in a society. They can make changes. (Young Tamil woman, interview March 2010)

While most of the groups and individuals that were interviewed were vocal about what they considered safe spaces (i.e. home and ethnically homogeneous spaces), universities represented spaces in which groups could be more explicitly vocal. Although most students tried to avoid politics, it was almost impossible for them not to be included. According to them, university spaces have become increasingly unsafe since the war. One representative of a Tamil student group explained how university politics might not be safe due to external threats:

But again, I have to mention that even in these types of networking there is politics. Sometimes we cannot negotiate in student politics, as the leaders acquire some outside powers [referring to political contacts]. Although we are interested in doing many things, we cannot do so due to some pressures. (Tamil university students, group interview March 2010)

Party politics are highly influential in most spheres of university life. Still, while most of the students placed themselves outside party politics, both Tamil and Muslim students found it more difficult to stay outside political spaces when adopting a strategy of vocal political involvement. For example, depending on which political group had most power in the university where the interviews were held, 
students were expected to contribute money for banners and to participate in protests organized by student unions. The politicized environment also restricted other activities because students felt under constant control and scrutiny, as one female student stated during an interview with Tamil students in March 2010: 'sometimes students are controlled in university. This is just because we are students.'

During the interviews, the youths expressed disappointment with politics and politicians. They felt they had been let down and controlled by politicians despite being considered future political leaders. The situation does not open up new avenues for political engagement because there is no space for challenging the official discourse on reconciliation and development, thus reflecting the unequal power relations between ethnicities and the majority and minority ethnic groups:

I don't engage in formal politics now. When I was a university student, through the student union I was engaged in formal politics ... within the university space. But outside we were too young and did not have enough power and money to engage in informal politics. Besides, people will look for where we are coming from ... what is our family background. (Young Tamil man, telephone interview March 2014)

In terms of politics, I think our expectations as youths were not fulfilled. Politics is different from political privileges. We are discriminated politically when searching for employment, without any proper reason. (Tamil student, group discussion with university students, March 2010)

The young people interviewed in 2014 reported that people in Sri Lanka have turned to 'informal politics' in order to gain sufficient personal power to ensure their individual needs. This implied using bribes to obtain jobs, and dealing with politicians' 'thugs' who pressurize potential followers. Such forms of political involvement contribute to insecurity and fear, and are happening at the same time as there is an observable tendency towards more vocal political presence. These new boundaries faced by young people coming from eastern Sri Lanka indicate that spaces for participation remain restricted. The youth feel delineated from the rest of the country and unsafe: 


\section{Inclusion and exclusion: societal and spatial power relations in youths' everyday politics}

We are still not in a position to speak freely. (Tamil university students, group interview March 2010)

This chapter has shown how young people's political engagement is shaped by their experiences of economic, social, and political exclusion. Feelings of exclusion from the official story of Sri Lankan politics have created a political presence among young Muslim and Tamil people in eastern Sri Lanka that despite a restricted social space are being articulated in multiple ways. The space where young people talk most freely about formal politics is in their homes, whereas political presence and involvement in public spaces take place in more concealed ways. Safe spaces to a large extent corresponded to where the interviewees felt their position was fully recognized - where they felt included. In spaces where their membership was precarious (including as citizens), their political engagement was increasingly restricted. Political involvement and being vocal thus varied according to the different levels of safety in the political spaces created by youths, and the nature of young people's encounters differed according to how much they placed themselves in an exposed position. Hence, the existing intersections between micro and macro politics as mentioned by O'Toole (2003), Skelton (2010), Häkli and Kallio, (2013), and Laketa (2015) are disrupted and limit effective political practices.

Young people's networks were actively employed to make safe spaces for political participation. The spaces in which young people employed a strategy of vocal political involvement had different degrees of exposure and security (also see Mitchell and Elwood, 2015, on young people's awareness about spatial politics, which affect their group identity). Particularly in activism and more vocal political involvement, one way of creating safe spaces was through support-networks. Young people would seldom work alone, but in groups, as a strategy to enhance their security. Nevertheless, such spaces of involvement for youths were restricted to the local level and largely outside the official discourses of the state at the national level. The opportunities that they hoped for after the war had 
materialized only to a limited extent, and this experience of exclusion and marginalization contribute to their political presence and involvement.

The studied young people's presence continued to develop between 2009 and 2014, the period during which they were interviewed. One theme that spurred strong feelings and political engagements were discussions around how identities other than belonging to the national polity of Sri Lanka dominated young people's positions. The interviewees' minority status was expressed uniformly across the Tamil and Muslim divide as more important than their identity as young people.

Accompanying young people's minority status is a strong sense of disillusionment, fear, and social exclusion: they do not feel they have anyone to represent them, and they feel vulnerable and struggle to find safe spaces in which they can talk openly. Power - both direct and relational - is a prominent feature in young people's lives (Skelton, 2010, p. 3): 'This should not just be about the effect of power on young people, but also the political power young people wield through their practices, resistance, strategies and challenges.' Difference and positioning are negotiated through the access to particular social relations and networks through which one may gain influence. In the case of youths in eastern Sri Lanka, the study revealed that their political action are conditioned by the history of marginalization and limited to political participation during war, development activities organized by the Sri Lankan state, and the continued military presence. Youths' concern with national politics is mainly due to the way the politics affect them locally or how the politics affect their ethnic groups. This concurs with the findings of Mills and Duckett (2015), that young people's lived experiences and own articulations and understandings of national identity highlight the fragmented and often contradictory spaces of youth citizenship and participation within the current political landscape. When discussing politics, their minority status is often highlighted as more important than their youth identity. Additionally, fear and anger are embedded in their ability to engage in vocal politics. This concerns youths' experiences of feeling that they are discriminated against and where they are treated differently, which angers them.

Changing conditions for political engagements among young people should be understood on different temporal scales such as following the historical changes in the country and the young people's movements towards adulthood. Over the few years that the young people in Sri Lanka were 
followed as part of a larger study, their possibilities for political engagements changed. First, social and physical spaces such as the university are no longer available to them because they are moving on, and moving towards adulthood. Second, young people are forced to become more competitive and individualistic and their political engagements have become more informal. This happens while ethnic backgrounds and histories continue to differ significantly. While Tamils have largely been deprived of the opportunity to have an active political life outside militarism, Muslims have continued to have opportunities for political participation through political parties since the civil war ended. However, both Tamil and Muslim interviewees expressed the same feelings of marginalization, and exclusion from political spaces and from having a political voice at the national level. Instead, they are enmeshed in societal and spatial power relations in a political environment that impacts on their identity construction and subjectivities.

This chapter has examined the axis between voiceless and vocal politics (after Kallio and Häkli, 2011), which concerns how much voice young people have in politics. In this regard, the aim to make more explicit the spatialities of the youth-centred perspectives on the political and politics has been discussed. In the studied context, young people manoeuver spaces of restricted freedom of speech and high security risks, and make safe spaces for political engagement. This shows that young people 'learn citizenship', by manoeuvring individually and collectively in a new political terrain (Jeffrey and Staeheli, 2015). Young people's claims of lack of access and socio-spatial exclusion unravel both earlier and contemporary exclusions. The political dimension of such exclusion rests on citizenship rights and consequently the range of formal and informal processes that determine people's inclusion in and exclusion from a variety of symbolic and material spaces and resources (Brun, 2003; Staeheli, Attoh, \& Mitchell 2013). Furthermore, young people adopt silence as a political strategy. Silence may be used in the sense of political presence and political involvement. Voiceless political presence cannot simply be equated with nonparticipation. In the studied context, youths' presence varies according to the social space in question and how they could manoeuver their presence.

The research findings presented in this chapter highlight that the aspirations of the interviewed youth revolved around, freedom to move, better education, political participation, suitable jobs and 
access to various important facilities. These opinions were related to their exclusions in mainstream society (Azmi and Lund 2010). Nevertheless, it is important to recognize that youth are potentially valuable contributors to rebuild the social and economic fabric Making available avenues for meaningful engagements will definitely lead us to see great dividends in the years to come.

\section{Acknowledgements}

Parts of this paper have been published in the Space \& Polity 2013/1 issue. We thank the editors for their valuable feedback to this chapter and Catriona Turner for copy editing.

\section{References}

Amarasuriya, H. (2009) Rethinking the nexus between youth, unemployment and conflict. In H. Amarasuriya, \& S. T. Hettige (Eds.), Politics and Social Exclusion of Youth in Sri Lanka (pp. 33-81). Colombo: Social Policy Analysis and Research Centre.

Azmi, F., \& Lund, R. (2010) Eastern Fish are still singing, Does any one listen? Self perception and identity on Social inclusion of Youth, in Batticaloa, Sri Lanka. In D. Herath, K. Hoglund, M. Schulz, \& K.T. Silva, K.T (Eds.), Post-War Reconstruction in Sri Lanka. Prospects and Challenges (pp.233-250). Kandy: International Centre for Ethnic Studies.

Azmi, F., Brun, C., \& Lund, R. (2013) Young people's everyday politics in post-conflict Sri Lanka. Space \& Polity, 17(1), 106-122.

Bartos, A. (2015) Children and young people's political participation: a critical analysis, in Kallio, K. P. and Mills, S. (2015) (eds) Politics, Citizenship and Rights, Vol. 7 of Skelton, T. (ed.) Geographies of Children and Young People. Springer: Berlin.

Bhalla, A., \& Lapeyre, F. (1997) Social exclusion: Towards an analytical and operational framework. Development and Change, 28(3), 413-433.

Brun, C. (2003) Local citizens or internally displaced persons? Dilemmas of long term displacement in Sri Lanka. Journal of Refugee Studies, 16(4), 376-397. 
Brun, C. (2013) 'I love my soldier': Developing responsible and ethically sound research strategies in a militarised society. In D. Mazurana, K. Jacobsen, \& L. Gale (Eds.), Research Methods in Conflict Settings: A View from Below (pp. 129-148). Cambridge: Cambridge University Press.

Brun, C., \& Lund, R. (2009) 'Unpacking' the narrative of a national housing policy in Sri Lanka. Norsk Geografisk Tidsskrift-Norwegian Journal of Geography, 63(1), 10-22.

Cass, N., Shove, E., \& Urry, J. (2005) Social exclusion, mobility and access. The Sociological Review, 53(3): 539-555.

Department of Census and Statistics. (2012) Provisional Report. Colombo: Government Press.

Fernando, L. (2002), Youth and politics: Why they rebel? In S. T. Hettige, \& M. Mayer (Eds.), Sri Lankan Youth: Challenges and Responses (pp. 119-138). Colombo: Friedric Ebert Stiftung.

Gingrich, L. G. (2008) Social exclusion and double jeopardy: The management of lone mothers in the market-state social field. Social Policy \& Administration, 42(4), 379-395.

Goodhand, J. (2012) Sri Lanka in 2011: Consolidation and militarization of the post-war regime. Asian Survey, 52(1), 130-137.

Häkli, J. \& Kallio, K. P. (2013) Editorial: Children and young people's politics in everyday life. Space and Polity, 17(1), 1-16.

Hettige, S. T. (2008) Role of youth in peaceful and sustainable development: Problems and prospects. In S.T. Hettige, \& M. Mayer (Eds.), Youth, Peace and Sustainable Development (pp. 3-22). Colombo: CEPA.

Hyndman, J. (2007) The securitization of fear in post-tsunami Sri Lanka. Annals of the Association of American Geographers, 97(2), 361-372.

International Crisis Group (2009) Development Assistance and Conflict in Sri Lanka: Lessons from the Eastern Province. Asia Report No. 165, 16 April 2009. Retrieved from http://www.crisisgroup.org/ /media/Files/asia/south-asia/srilanka/165Development\%20assistance_and_conflict_in_sri_lanka__lessons_from_the_eastern _province

Ismail, Q. (2001) Speaking to Sri Lanka. Interventions, 3(2), 296-308. 
Jeffrey, C. (2008) 'Generation nowhere': Rethinking youth through the lens of unemployed young men. Progress in Human Geography, 32(6), 739-758.

Jeffrey, A. \& Staeheli, L.A. (2015) Learning citizenship: civility, civil society and the possibilities of citizenship, in Kallio, K. P. and Mills, S. (2015) (eds) Politics, Citizenship and Rights, Vol. 7 of Skelton, T. (ed.) Geographies of Children and Young People. Springer: Berlin.

Kallio, P. K., \& Häkli, J. (2011) Tracing children's politics. Political Geography, 30(2), 99-109.

Laketa, S. (2015) Youth identities and geopolitical contestations: the case of Mostar, Bosnia and Herzegovina, in Kallio, K. P. and Mills, S. (2015) (eds) Politics, Citizenship and Rights, Vol. 7 of Skelton, T. (ed.) Geographies of Children and Young People. Springer: Berlin.

Lund, R. (2012) Researching crisis - Recognizing the unsettling experience of emotions. Emotion, Space and Society, 5(2), 94-102.

Mills, S. \& Duckett, J. (2015) Representing, reproducing and re-configuring the nation: geographies of youth citizenship and devolution, in Kallio, K. P. and Mills, S. (2015) (eds) Politics, Citizenship and Rights, Vol. 7 of Skelton, T. (ed.) Geographies of Children and Young People. Springer: Berlin.

Ministry of Youth Affairs and Skills Development (2014) National Youth Policy Sri Lanka. Colombo: Ministry of Youth Affairs and Skills Development.

Mitchell, K. \& Elwood, S. (2015) Counter mapping for social justice, in Kallio, K. P. and Mills, S. (2015) (eds) Politics, Citizenship and Rights, Vol. 7 of Skelton, T. (ed.) Geographies of Children and Young People. Springer: Berlin.

Moore, D. ( 2000) Levelling the playing fields \& embedding illusions: 'Post-conflict' discourse \& neliberal 'development' in war-torn Africa. Review of African Political Economy, 27(83), 11-28.

O’Toole, T. (2003) Engaging with young people's conceptions of the political. Children's Geographies, 1(1), 71-90.

Rajapaksa, M. (2009) Address by HE President Mahinda Rajapaksa at the ceremonial opening of Parliament, Sri Jayawardahanapura - Kotte, May 19, 2009. Retrieved from http://www.president.gov.lk/speech_New.php?Id+7> 
Ruwanpura, K. (2009) Putting houses in place: Re-building communities in post-tsunami Sri Lanka. Disasters, 33(3), 436-456.

Sen, A. (2000) Social Exclusion: Concept, Application, and Scrutiny. Social Development Papers No. 1. Manila: Asian Development Bank.

Schubert, A. (2013) Victorious Victims: An Analysis of Sri Lanka's Post-War Reconciliation Discourse. ICES Research Paper No. 6. Colombo: ICES.

Scott, J.C. (1985) Weapons of the Weak: Everyday Forms of Peasant Resistance. London: Yale University Press.

Skelton, T. (2010) Taking young people as political actors seriously: Opening the borders of political geography. Area, 42(2), 145-151.

Staeheli, L. A., Attoh, K., \& Mitchell, D. (2013) Contested engagements: Youth and the politics of citizenship. Space and Polity, 17(1), 88-105.

Thrift, N. (2004) Intensities of feeling: Towards a spatial politics of affect. Geografiska Annaler, 86B, $57-78$.

Vandeyar, S. (2013) Youthscapes: The politics of belonging for 'Makwerekwere' youth in South African schools. Citizenship Studies, 17(3-4), 447-463.

Uyangoda, J. (2011) Sri Lanka in 2010. Asian Survey, 51 (1), 131-137.

Uyangoda, J. (2012) Healing after the war: Thinking beyond the solitudes. In Herath, D., \& Silva, K. T. (Eds.), Healing the Wounds: Rebuilding Sri Lanka After the War (pp. 18-32). Colombo and Kandy, ICES.

Wood, B. E. (2012) Crafted within liminal spaces: Young people's everyday politics. Political Geography, 31 (6), 337-346. 